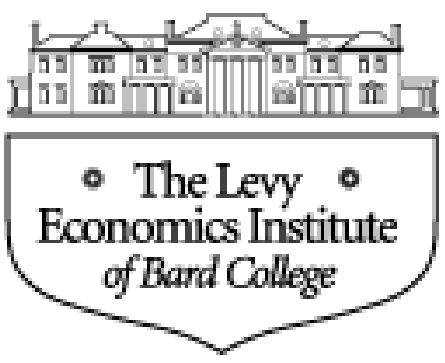

Working Paper No. 472

\title{
The Adequacy of Retirement Resources among the Soon-to-Retire, 1983-2001
}

\author{
by \\ Edward N. Wolff \\ New York University and \\ The Levy Economics Institute of Bard College
}

August 2006

The Levy Economics Institute Working Paper Collection presents research in progress by

Levy Institute scholars and conference participants. The purpose of the series is to disseminate ideas to and elicit comments from academics and professionals.

The Levy Economics Institute of Bard College, founded in 1986, is a nonprofit, nonpartisan, independently funded research organization devoted to public service. Through scholarship and economic research it generates viable, effective public policy responses to important economic problems that profoundly affect the quality of life in the United States and abroad.

\author{
The Levy Economics Institute \\ P.O. Box 5000 \\ Annandale-on-Hudson, NY 12504-5000 \\ http://www.levy.org
}




\begin{abstract}
A central issue confronting soon-to-retire workers (i.e., those aged 47-64) is whether they will have command over enough resources (both private and public) to maintain a decent standard of living in retirement. Typically, the adequacy of projected retirement income is judged in relation to some absolute standard (e.g., poverty threshold) and preretirement income ("replacement rate"). Using data from the Federal Reserve Board's Survey of Consumer Finances for 1983, 1989, and 2001, I find that expected retirement income grew robustly from 1989 to 2001 (by 38 percent in real terms) and the share with expected retirement income less than twice the poverty line fell by 5 percentage points. The percentage-point decline was even greater for minority households (11.6) and single females (5.7). The change in the share with replacement rates over 50 percent was 4.5 percentage points, though in this case much lower for minorities ( 0.9 percentage points) and single females ( 1.8 percentage points). However, percentage point changes for minorities and single females were much smaller, at 75 percent and a 100 percent replacement rates, respectively. Moreover, retirement wealth is very unevenly distributed. Whites and married couples had substantially larger wealth accumulations than their respective counterparts.
\end{abstract}

JEL Classifications: J32, D31, H55

Keywords: pensions, Social Security, wealth, retirement adequacy 


\section{INTRODUCTION}

A central issue confronting the soon-to-retire workers (i.e., in the age group 47-64) is whether they will have command over enough resources (both private and public) to maintain a decent standard of living in retirement. Typically, the adequacy of projected retirement income is judged in relation to some absolute standard (e.g., poverty threshold) and preretirement income ("replacement rate"). In a previous study, utilizing data up to 1998 (Wolff 2002b), I found that among the households headed by a soon-to-retire worker, the proportion expected to be in poverty or unable to replace at least half their preretirement income rose from 1989 to 1998. Since 1998 until 2001, at least, the economy boomed, the stock market surged, and the unemployment rate fell sharply. The principal focus of this paper is to update the findings of the earlier study utilizing the 2001 Survey of Consumer Finances in order to shed light on the retirement income security of the soon-to-retire. Particular attention will be paid to the adequacy of pensions, Social Security, and financial wealth in relation to preretirement income.

I find that retirement income adequacy did indeed improve from 1989 to 2001. For instance, the share of households between 47 and 64 that could expect to have retirement incomes that were less than twice the poverty line declined from 40 percent in 1989 to 35 percent in 2001. Also, the share of households that could hope to replace at least half of their projected preretirement income at age 65 in retirement rose from 49 to 53 percent.

Despite these improvements, there were still large gaps in retirement preparedness for many households. First and foremost, it appears that improvements in pension coverage may have leveled off. By 2001, 24 percent of households in this age group could still expect to retire without a private pension plan, either a traditional defined benefit plan or a defined contribution plan.

Further, retirement wealth was unequally distributed. The level of retirement wealthprivate pensions plus Social Security wealth — was substantially higher on average than for the median household, suggesting large inequities in the wealth distribution. These inequities are the result of an unequal distribution of private pension assets rather than of Social Security wealth.

Because Social Security offered almost universal coverage and because Social Security wealth grew, on average, at a respectable pace, it actually had a relatively larger effect on the retirement preparedness of vulnerable groups than private pension wealth. Among African- 
Americans and single women, Social Security played a comparatively stronger role in retirement income adequacy than private pension wealth in comparison to their respective counterparts.

Although there were important gains in retirement income adequacy, many households were still inadequately prepared for retirement in 2001. Taking a generally accepted replacement ratio of 75 percent of retirement income relative to preretirement income as a threshold, the data show that two thirds of households between the ages of 47 to 64 would still fall below this threshold. The shortfalls are larger for African-American or Hispanic households and for single women.

Seeing how well prepared for retirement today's near elderly are and how this preparedness has changed in the 1990s sheds some light on important policy conclusions. For instance, the fact that many households are still inadequately prepared for retirement is closely linked to the fact that they have little or no private pension wealth. This is especially true for African-American and Hispanic households and for single women. Hence, policies that could help to improve private pension coverage and wealth accumulation for these groups should be considered more seriously. Further, private pension wealth plays an important role for retirement income adequacy for those that have it. Thus, public policy should focus on securing private pension wealth to ensure that the accumulated savings are available when people retire. And finally, Social Security appears to be at the heart of improving retirement income security for many groups. Consequently, public policy should focus on securing Social Security for the long-term as an important step to improving retirement income adequacy.

The remainder of the paper is organized as follows. The next section of the paper (Section 2) provides a review of the pertinent literature on retirement wealth and retirement adequacy. Section 3 describes the data sources and develops the accounting framework used in the analysis. Section 4 shows time trends in standard measures of household wealth over the 1983-2001 period. Section 5 investigates changes in retirement wealth and total (augmented) household wealth. In Section 6, I present measures of retirement adequacy for age group 47 to 64 . Concluding remarks are made in Section 7.

\section{LITERATURE REVIEW}

Previous work has focused on just one or a few of the aspects of the adequacy of retirement income or wealth. For instance, a number of papers have presented estimates of Social Security and/or 
pension wealth. The seminal paper on this topic is Feldstein (1974), who introduced the concept of Social Security wealth and developed its methodology. In a follow-up paper, Feldstein (1976), using the Federal Reserve Board's 1962 Survey of Financial Characteristics of Consumers (SFCC), found that the inclusion of Social Security wealth had a major effect on lowering the overall inequality of (total) household wealth.

Wolff followed up this work by examining the distributional implications of both Social Security and private pension wealth. Wolff (1987) used the 1969 Measurement of Economic and Social Performance (MESP) database and showed that, while Social Security wealth had a pronounced equalizing effect on the distribution of "augmented wealth" (defined as the sum of marketable wealth and retirement wealth), pension wealth had a disequalizing effect. The sum of Social Security and pension wealth had, on net, an equalizing effect on the distribution of augmented wealth. Wolff (2002a) re-examined the distributional effects of retirement wealth based on the Survey of Consumer Finances (SCF) from 1983 to 1998 and found that Social Security continued to have a mitigating distributional effect. With respect to defined contribution wealth, however, Wolff (forthcoming) found that the rise in defined contribution wealth has led to greater wealth inequality. Kennickell and Sunden (1999), who based their study on the 1989 and 1992 SCF, also found a net equalizing effect from the inclusion of pension and net Social Security wealth in calculating total household wealth.

Several papers have used the Health and Retirement Survey (HRS). Gustman et al. (1997) found that in 1992, pensions, Social Security, and health insurance accounted for half of the wealth for those ages 51-61; for 60 percent of total wealth for those in wealth percentiles $45-55$ and for 48 percent of wealth for those in wealth percentiles 90-95. In a follow-up study, Gustman and Steinmeier (1998) found that for 51- to 61-year-old's pensions were held by two-thirds of households and accounted for one-quarter of accumulated wealth on average. Social Security benefits accounted for another quarter of total wealth.

Several studies have documented changes in pension coverage, particularly the decline in defined benefit pension coverage among workers over the last two decades. Bloom and Freeman (1992), using Current Population Surveys (CPS) for 1979 and 1988, were among the first to call attention to the decline in defined benefit pension coverage. They reported that the percentage of all workers age 25-64 covered by these plans fell from 63 percent to 57 percent over this period. Even 
and Macpherson (1994) showed a particularly pronounced drop in defined benefit pension coverage among workers with low levels of education.

A related topic of interest is whether defined contribution plans have substituted for defined benefit plans. Popke (1999), using employer data (5500 filings) for 1992, found that, indeed, 401(k) and other defined contribution plans have substituted for terminated defined benefit plans and that the offering of a defined contribution plan raises the chance of a termination in defined benefit coverage. On the other hand, Poterba, Venti, and Wise (1998), using HRS data for 1993, found that the growth of 401(k) plans did not substitute for other forms of household wealth and, in fact, raised household net worth relative to what it would have been without these plans.

A Department of Labor report issued in 2000 found that a large proportion of workers, especially low-wage, part-time, and minority workers, were not covered by private pensions. The coverage rate of all private-sector wage-and-salary workers was 44 percent in 1997. The low coverage for part-time, temporary, and low-wage workers appeared to be ascribable to the proliferation of 401(k) plans and the frequent requirement for employee contributions to such plans. The report also found important racial differences, with 47 percent of white workers participating but only 27 percent of Hispanics. Another important distinction was union membership, with 70 percent of unionized workers covered by a pension plan but only 41 percent of non-unionized workers. Moreover, pension participation was found to be highly correlated with wages. While only 6 percent of workers earnings less than $\$ 200$ per week were involved in a pension plan, 76 percent of workers earning more than $\$ 1,000$ per week participated.

\section{Retirement Income Adequacy}

Calculations of retirement income adequacy typically relate retirement consumption to preretirement consumption in three possible ways. First, a household may be considered adequately prepared for retirement if it can maintain a similar real level of consumption as during its working years. Usually, 80 percent of preretirement income is thus considered adequate since the income needs of retirees are likely to be lower than those of workers (Aon 2001). Households no longer need to save for retirement, taxes are lower, work related expenses disappear, the family size of retirees is smaller than that of workers, and households eventually pay off their debt (McGill et al. 1996). Second, retirement income adequacy may be defined as a constant nominal level of consumption during retirement as during working years. This means that consumption needs are 
expected to decline during retirement over time, but in a somewhat arbitrary fashion. Third, real consumption may decline if the marginal utility of consumption is held constant and uncertainty about income and life expectancy are introduced (Engen, Gale, and Uccello 1999). As households must consider an uncertain future, their marginal utility of certain consumption today is higher than the marginal utility of uncertain consumption in the future.

A number of studies have analyzed retirement savings adequacy with differing results. For instance, Gustman and Steinmeier (1998) found, using the HRS, that the average household could replace 60 percent of preretirement income in real terms and 86 percent of preretirement income in nominal terms. The finding for the nominal replacement ratio led the authors to conclude that households, on average, were adequately prepared for retirement. Engen, Gale, and Uccello (1999), using the Survey of Income and Program Participation (SIPP) and the SCF, estimated that 40-50 percent of households fell short of what they needed for adequate retirement income. But as their calculations are based on a stochastic model, only 50 percent of households should be expected to meet the target retirement savings. The average replacement ratio for the median income quintile household, calculated by Engen, Gale, and Uccello (1999), is still 72 percent, leading the authors to conclude that households are close to being adequately prepared for retirement. In an updated study, Engen, Gale, and Uccello (2002) found that the upswing in stock prices from 1995 to 1998 did not substantially alter their earlier findings on retirement income. This suggests that much of the increase in retirement wealth was concentrated among households who were already adequately prepared for retirement. Further, Haveman et al. (2003), using Social Security's New Beneficiary Data System (NBDS), found that retired beneficiaries had a median replacement ratio of about 80 percent, and that only 30 percent of households had a replacement ratio of less than 70 percent in 1982.

By contrast, several studies concluded that households were inadequately prepared for retirement. For instance, Moore and Mitchell (2000) found, using the 1992 HRS, that the median wealth household would have to save an additional 16 percent of earnings annually if it were to retire at age 62 and an additional 7 percent annually for retirement at age 65 to finance an adequate real replacement ratio. Their estimate of a savings rate of 7.3 percent for households wishing to retire at age 65 was three times as much as what households actually saved (Mitchell and Moore 1998). This meant that households had, on average, between 75 percent and 88 percent—depending on marital status - of what they needed when retiring at 65 in 1992 (Mitchell and Moore 1998). 
Also, Gustman and Steinmeier's (1999) figures show that, based on real replacement ratios, the average household had 28 percent less than adequate retirement savings. Lastly, Wolff (2002b) concluded that 61 percent of households could not replace 75 percent of their preretirement income in retirement based on data from 1998, up from 56 percent of households in 1989.

One issue to consider, though, is what a shortfall relative to adequate savings means. In some cases, a shortfall will still allow households to finance most of their expected consumption. Engen, Gale, and Uccello (1999) point out that the households used in Mitchell and Moore (1998) could still finance more than 90 percent of the consumption prescribed by their model with no additional savings. Similarly, Haveman et al.'s (2003) study shows that about 20 percent of households have a replacement ratio between 70 percent and 80 percent. That is, one fifth of households have more than 90 percent, but less than 100 percent, of what is generally assumed for retirement income adequacy — 80 percent of preretirement earnings.

As wealth is unequally distributed, there may be a large share of households for which the shortfalls are larger. Engen, Gale, and Uccello (1999) calculated that households in the 75th percentile - the closest income percentile for average (not median) income - had 121 percent to 172 percent of what they needed for retirement. For the median household, the same ratios ranged from 47 percent to 124 percent. Thus, the median household reached only 62 percent of the preparedness of the average household in 1992. Moreover, Wolff (2002a) documented that the gap between average wealth and median wealth to income ratios increased further by 1998. Following the unequal distribution of wealth, a large share of households are likely to experience retirement consumption shortfalls ${ }^{1}$. Gustman and Steinmeier (1999) found that households in the bottom quartile had nominal replacement ratios of 50 percent and real replacement rates of 33 percent, compared to nominal replacements of 121 percent and real replacement rates of 81 percent for the top quartile. Also, Wolff (2002b) found that 16 percent of households could replace less than 25 percent of their preretirement income and that 43 percent of households could replace less than half of their preretirement income during retirement in $1998^{2}$. Lastly, Haveman et al. (2003) found that

\footnotetext{
${ }^{1}$ Shortfalls in retirement savings vary with household demographics. Mitchell et al. (2000) and Engen, Gale, and Uccello (1999) found that black and Hispanic married households experienced a larger shortfall in retirement income adequacy than whites, and that less education resulted in a worsening of retirement income adequacy. Mitchell and Moore (1998) also found that single households were less adequately prepared than married ones.

2 In comparing these figures with findings of other studies, e.g., Haveman et al. (2003), it needs to be kept in mind that, for instance, Haveman et al. (2003) only considered Social Security earnings for their replacement ratio calculations, thus understating the level of household income. Also, Wolff (2002b) considered the wealth of households nearing
} 
single men were more likely be inadequately prepared than single women, who were in turn less likely than married couples to be adequately prepared for retirement.

To make ends meet in retirement, when facing an income shortfall, households will have to curtail their retirement consumption. In fact, one of the distinguishing features between studies that conclude that households are adequately prepared for retirement and those that do not is the consumption pattern in retirement. For instance, Engen, Gale, and Uccello (1999) and Gustman and Steinmeier (1999) conclude that households are adequately prepared for retirement based on the fact that real retirement consumption declines with age in their models. Similarly, Haveman et al. (2003) base their conclusions on the assumption of declining consumption in retirement, albeit at a slower pace than Gustman and Steinmeier (1999).

In the past few years, a number of studies have looked at the changes of retirement income adequacy over time. Wolff (2002b) found that the share of households between the ages of 47 and 64 that could replace less than 75 percent of their current income in retirement rose from 56.1 percent in 1989 to 61.2 percent in 1998. In comparison, Engen, Gale, and Uccello (2002) found that retirement income adequacy, by their stochastic definition, had changed little from 1995 to 1998. Lastly, Smith (2003) found, using data from the Panel Study of Income Dynamics (PSID) and the CPS, that median after-tax income replacement ratios in retirement showed an increasing trend, particularly since the early 1990s.

\section{DATA SOURCES AND ACCOUNTING FRAMEWORK}

The principal data sources used for this study are the 1983, 1989, and 2001 Survey of Consumer Finances (SCF) conducted by the Federal Reserve Board. Each survey consists of a core representative sample combined with a high-income supplement. The SCF provides considerable detail on both pension plans and Social Security contributions. The SCF also gives detailed information on expected pension and Social Security benefits for both husband and wife. For 1983, the Federal Reserve Board also made its own calculations of the wealth equivalent value of both

retirement, whereas Haveman et al. (2003) considered wealth for those who were retired. Obviously households can increase their savings before entering retirement and occasionally while in retirement. 
expected pension benefits and Social Security benefits. I use these estimates in this paper. However, this has not been done for other years. ${ }^{3}$

The basic wealth concept used here is marketable wealth (or net worth, NW), which is defined as the current value of all marketable or fungible assets, less the current value of debts. Total assets are the sum of: (1) the gross value of owner-occupied housing; (2) other real estate; (3) cash and demand deposits; (4) time and savings deposits, certificates of deposit, and money market accounts; (5) bonds and other financial securities; (6) the cash surrender value of life insurance plans; (7) the current market value of Defined Contribution pension plans, including IRAs, Keogh, and 401(k) plans; (8) corporate stock and mutual funds; (9) net equity in unincorporated businesses; and (10) equity in trust funds. Total liabilities are the sum of: (1) mortgage debt; (2) consumer debt, including auto loans; and (3) other debt. It should be stressed that the standard definition of net worth includes the market value of DC pension plans. ${ }^{4}$

A word should be said on why I use the SCF instead of the newer Health and Retirement Survey (HRS), which has much more complete data on earnings histories and has employerprovided information on individual DB pension plans. There are three reasons. First, the SCF provides much better data on the assets and liabilities that constitute marketable net worth. Second, the SCF data date from 1983, whereas the HRS data start only in 1992. Third, the age coverage of the HRS is limited, whereas the SCF covers the whole population.

The imputation of both pension and Social Security wealth involves a large number of steps, which is summarized below.

\section{A. Pension Wealth}

For retirees (r) the procedure is straightforward. Let PB be the pension benefit currently being received by the retiree. The SCF questionnaire indicates how many pension plans each spouse is

\footnotetext{
${ }^{3}$ The underlying data are not available for the 1983 SCF to re-do these estimates in exactly the same form as for 1989 and 2001, though I try to follow their method as much as possible for these two years (see below). The difference in methodology may introduce compatibility problems between the 1983 estimates and those of the other two years. Moreover, pension and Social Security wealth imputations in the 1983 data are not available for households under the age of 40 .

${ }^{4}$ Only assets that can be readily converted to cash (that is, "fungible" ones) are included. As a result, consumer durables, such as automobiles, televisions, furniture, household appliances, and the like, are excluded here since these items are not easily marketed or their resale value typically far understates the value of their consumption services to the household.
} 
involved in and what the expected (or current) pension benefit is. The SCF questionnaire also indicates whether the pension benefits remain fixed in nominal terms over time for a particular

beneficiary or is indexed for inflation. In the case of the former, the (gross) Defined Benefit pension wealth is given by:

$$
\text { (1) } \mathrm{DB}_{\mathrm{r}}=\int_{0} \mathrm{~PB}\left(1-\mathrm{m}_{\mathrm{t}}\right) \mathrm{e}^{-\delta \mathrm{t}} \mathrm{dt}
$$

where $\mathrm{m}_{\mathrm{t}}$ is the mortality rate at time (t) conditional on age, gender, and race, ${ }^{5}$ the discount rate $(\delta)$, which is set at 5 percent ( 2 percent when PB is indexed for inflation), and the integration runs from the person's current age to age $109 .^{6}$

Among current workers (w) the procedure is somewhat more complex. The SCF provides detailed information on pension coverage among current workers, including the type of plan, the expected benefit at retirement or the formula used to determine the benefit amount (for example, a fixed percentage of the average of the last five year's earnings), the expected retirement age when the benefits are effective, the likely retirement age of the worker, and vesting requirements. Information is provided not only for the current job (or jobs) of each spouse but for up to five past jobs as well. On the basis of the information provided in the SCF and on projected future earnings, future expected pension benefits $\left(\mathrm{EPB}_{\mathrm{w}}\right)$ are then projected to the year of retirement or the first year of eligibility for the pension. Then the present value of pension wealth for current workers $(w)$ is given by:

$$
\text { (2) } \mathrm{DB}_{\mathrm{w}}=\int_{\mathrm{LR}} \mathrm{EPB}\left(1-\mathrm{m}_{\mathrm{t}}\right) \mathrm{e}^{-\delta t} \mathrm{dt}
$$

where RA is the expected age of retirement and $L R=A$ - RA is the number of years to retirement. As above, and the integration runs from the expected age of retirement to age $109 .^{7}$

\footnotetext{
${ }^{5}$ The mortality rate data are from the U.S. Bureau of the Census, Statistical Abstract of the United States, 1985, 1991, and 2003, Washington, D.C., U.S. Government Printing Office.

${ }^{6}$ I also used as alternatives real discount rates of $1.5,2.5$, and 3.0 percent. The results of the analysis are not materially altered (and not shown in the paper).

${ }^{7}$ Technically speaking, the mortality rate $\left(\mathrm{m}_{\mathrm{t}}\right)$ associated with the year of retirement is the probability of surviving from the current age to the age of retirement. The discount rate is again set at 5 percent ( 2 percent if PB is indexed).
} 
It should be noted that the calculations of DB pension wealth for current workers are based on employee response, including his or her stated expected age of retirement, not on employerprovided pension plans. A couple of studies have looked at the reliability of employee-provided estimates of pension wealth by comparing self-reported pension benefits with estimates based on provider data. Using data from the 1992 wave of the HRS, both Gustman and Steinmeier (1999) and Johnson, Sambamoorthi, and Crystal (2000) found that individual reports of pension benefits varied widely from those based on provider information. However, the latter also calculated that the median values of DB plans from the two sources were quite close (about a 6 percent difference).

\section{B. Social Security Wealth}

For current Social Security beneficiaries (r), the procedure is again straightforward. Let SSB be the Social Security benefit currently being received by the retiree. Again, the SCF provides information for both husband and wife. Since Social Security benefits are indexed for inflation, (gross) Social Security wealth is given by:

$$
\text { (3) } \quad \mathrm{SSW}_{\mathrm{r}}=\int_{0} \operatorname{SSB}\left(1-\mathrm{m}_{\mathrm{t}}\right) \mathrm{e}^{-\delta \mathrm{t}} \mathrm{dt}
$$

where it is assumed that the current Social Security rules remain in effect indefinitely. ${ }^{8}$

The imputation of Social Security wealth among current workers is based on the worker's projected earnings history estimated by regression equation. The steps are, briefly, as follows. First, coverage is assigned based on whether the individual expects to receive Social Security benefits and on whether the individual was salaried or self-employed. Second, on the basis of the person's earnings history, the person's Average Indexed Monthly Earnings (AIME) is computed. Third, on the basis of existing rules, the person's Primary Insurance Amount (PIA) is derived from AIME. Then,

$$
\text { (4) } \mathrm{SSW}_{\mathrm{w}}=\int_{\mathrm{LR}} \operatorname{PIA}\left(1-\mathrm{m}_{\mathrm{t}}\right) \mathrm{e}^{-\delta^{* * t}} \mathrm{dt} \text {. }
$$

As with pension wealth, the integration runs from the expected age of retirement to age $109 .{ }^{9}$

\footnotetext{
${ }^{8}$ Separate imputations are performed for husband and wife and an adjustment in the Social Security benefit is made for the surviving spouse. The discount rate is again set at 2 percent.

${ }^{9}$ As with pension wealth, the mortality rate, $\mathrm{m}_{\mathrm{t}}$, associated with the year of retirement is the probability of surviving from the current age to the age of retirement and the discount rate is set at 2 percent.
} 
Here, too, it should be noted that estimates of Social Security wealth are based on reported earnings at a single point in time. These estimates are likely to be inferior to those based on longitudinal work histories of individual workers (see, for example, Smith, Toder, and Iams 2001, whose estimates are based on actual Social Security work histories.) In fact, actual work histories do show much more variance in earnings over time than one based on a human capital earnings function projection. Moreover, they also show many periods of work disruption that I cannot adequately capture here. However, I do have some retrospective information on work history provided by the respondent. In particular, each individual is asked to provide data on the total number of years worked full-time since age 18, the number of years worked part-time since age 18 , and the expected age of retirement (both from full-time and part-time work). On the basis of this information, it is possible to approximate the total number of full-time and part-time years worked over the individual's lifetime and use these figures in the estimate of the individual's AIME.

Nonetheless, since my estimates of SSW assume a continuous work life, I am likely to be overstating the value of SSW for many workers. This is likely to bias upward my estimates of mean and median SSW, as well as a downward bias in the variability of Social Security wealth. It may also lead to an understatement of the correlation between net worth and SSW.

\section{Employer Contributions to Defined Contribution Plans}

So far, I have treated Defined Benefit and Defined Contribution pension wealth, as well as SSW, as comparable concepts. However, there are important differences in their estimation. Most notably, the calculation of DB wealth is estimated on the basis of the future stream of pension benefits on the assumption that the employee remains at his or her firm of employment until the person's expected retirement date. The computation of SSW is also based on the assumption that the worker remains at work until the person's expected retirement date. On the other hand, the Defined Contribution valuation is based on the current market value of DC plans.

To put DB (and SSW) and Defined Contribution wealth (DC) on an "equal footing," I project forward the employer contribution to DC plans, like 401(k)s. If we assume, as in the case of DB pensions, that workers remain at their company until retirement, and that the terms of their DC contract with their employer stays the same, then it is possible to do this. In most cases, the employer contribution is a fixed percentage of the employee's salary. On the basis of the estimated human capital earnings functions for each worker, it is possible to calculate the annual stream of 
future employer contributions to the DC plan until retirement (which I call DC2). ${ }^{10}$ The addition of DC2 to household wealth puts the treatment of DC pension wealth roughly on a par with that of DB pension wealth, since both represent future additions to household wealth from the employer.

The SCF questionnaire indicates how many DC pension plans each spouse has (up to three per spouse). ${ }^{11}$ Information on the employer contribution to DC pensions plans is recorded in two ways. First, in some cases, the contribution is given as a flat dollar amount. Though it is not indicated in the survey data whether the dollar contribution is indexed to inflation over time, I assume that it is indexed to the CPI, which seems the more likely arrangement. ${ }^{12}$ Let EMPAMT be the dollar amount of the employer contribution to the DC plan. Then, the present value of the stream of future employer contributions, $\mathrm{DC} 2_{\mathrm{a}}$, is given by:

\section{(5) $\quad \mathrm{DC} 2_{\mathrm{a}}={ }_{0} \int^{\mathrm{LR}} \operatorname{EMPAMT}\left(1-\mathrm{m}_{\mathrm{t}}\right) \mathrm{e}^{-\delta \mathrm{t}} \mathrm{dt}$}

where $\mathrm{m}_{\mathrm{t}}$ is the mortality rate at time $(\mathrm{t})$ conditional on age, gender, and race; and the discount rate $(\delta)$ is set at 2 percent. ${ }^{13}$ The integration runs from the current year to LR, where RA is the expected age of retirement and $\mathrm{LR}=\mathrm{A}-\mathrm{RA}$ is the number of years to retirement.

Second, in most cases, the employer contribution is given as a percent of earnings. If we assume that the proportion, EMPPER, is fixed over time, then $\mathrm{DC} 2_{\mathrm{b}}$, is given by:

$$
\text { (6) } \quad D C 2_{b}={ }_{0} \int^{L R} \text { EMPPER } \cdot E^{*}\left(1-m_{t}\right) e^{-\delta t} d t
$$

where $\mathrm{E}^{*} \mathrm{t}$ is the predicted earnings of the worker at time $(\mathrm{t})$ in constant dollars.

\footnotetext{
${ }^{10}$ Moreover, the 1983 data do not present a problem, since DC wealth was a trivial amount, so that we can again safely ignore this in the wealth comparison between 1983 on the one hand and 1989 and 2001 on the other hand.

${ }^{11}$ The SCF records DC plans only for the main job of each respondent. No information on DC plans is provided for secondary employment. This does not appear to be a significant problem because in 2001, 99.4 percent of the total labor earnings of the head and 98.8 percent of that of the spouse came from the person's primary job.

${ }^{12}$ This will, if anything, bias upward the estimated employer contribution to the DC pension plan

${ }^{13}$ This calculation assumes that the real rate of return on DC assets equals the discount rate $\delta$. It should also be noted that past employer contributions to DC plans are already included in the current market value of DC wealth.
} 
Estimates are provided for the following components of household wealth:

(7) $\quad \mathrm{DC}=\mathrm{DC} 1+\mathrm{DC} 2$

where DC1 is the current market value of households' Defined Contribution accounts.

(8) $\quad \mathrm{NW}=\mathrm{NWX}+\mathrm{DC}$

where NWX is marketable household wealth excluding DC. Total pension wealth PW is given by:

(9) $\quad \mathrm{PW}=\mathrm{DB}+\mathrm{DC}$

Retirement wealth RW is then given as the sum of pension and Social Security wealth:

(10) $\quad \mathrm{RW}=\mathrm{PW}+\mathrm{SSW}$

Finally, augmented household wealth, AW, is given by:

(11) $\mathrm{AW}=\mathrm{NWX}+\mathrm{RW}$

\section{TIME TRENDS IN STANDARD MEASURES OF NET WORTH}

Table 1 documents a robust growth in wealth during the 1990s. After rising by 7 percent between 1983 and 1989, real median wealth among all households was 16 percent greater in 2001 than in 1989. ${ }^{14}$ As a result, median wealth grew slightly faster between 1989 and 2001 (1.32 percent per year) than between 1983 and 1989 (1.13 percent per year). Mean net worth was 65 percent higher in 2001 than in 1983 and 44 percent larger than in 1989. Mean wealth grew quite a bit faster between 1989 and 2001 (3.02 percent per year) than from 1983 to 1989 (2.27 percent per year). Moreover,

\footnotetext{
${ }^{14}$ The CPI-U is used as the deflator for both income and wealth.
} 
mean wealth grew almost three times as fast as the median, suggesting widening inequality of wealth over these years.

The robust performance of median net worth over the 1990s contrasts sharply to trends in median income. Median household income, based on the SCF data, after gaining 3.0 percent between 1983 and 1989, grew by 9.2 percent from 1989 to 2001 -slower than median net worth in both periods. The net change over the whole period was 12.5 percent. In contrast, mean income rose by 8 percent from 1983 to 1989 and by another 26 percent from 1989 to 2001, for a total change of 36 percent. $^{15}$

The wealth picture changes as households grow older (table 2). For one, average wealth was substantially higher for older households. Households between the ages of 47 and 64 had, on average, $\$ 598,300$ in total wealth in 2001,57 percent higher than for the population at large. The growth in mean net worth over the 1983-2001 period was a little lower than average for age group 47-64, while the growth in median net worth was a little higher. The growth in both mean and median income, on the other hand, was above average for age group 47-64.

The average wealth to income ratio increased from 5.0 to 5.6 - a more than 10 percent gain over this period for all households. In comparison, the wealth to income ratio for households nearing retirement grew by 11 percent from 5.9 to 6.5. In other words, older households had a slightly higher wealth to income levels and increased those somewhat more than the population at larger.

\section{RETIREMENT AND AUGMENTED WEALTH}

The only form of retirement wealth that is almost universally held is Social Security wealth (see table 3). By 2001, 98 percent of households between the ages of 47 and 64 were covered by Social Security, up from 92 percent in 1983. In comparison, private pension coverage continues to show large holes that are only very slowly being filled. For instance, the share of households between 47 and 64 with a DC or DB plan was 76 percent, compared to 98 percent with Social Security coverage. However, pension coverage among this age group rose from 70 percent in 1983 to 76 percent in 2001 . The increase in overall pension coverage came about from the very rapid

\footnotetext{
${ }^{15}$ The Current Population Survey (CPS) data show somewhat different time trends, with median income rising by 11 percent between 1983 and 1989 and then only 2.3 percent from 1989 to 2001, and mean income growing by 16 and 12 percent, respectively.
} 
expansion of the DC system, with the share with DC coverage ballooning from 12 to 62 percent over these 18 years. In contrast, DB coverage fell rather rapidly as well.

In 2001, 98 percent of all households in the preretirement age groups (47 to 64) had some form of retirement wealth. The share covered by some form of retirement wealth was up slightly, from 97 percent in 1983.

From 1983 to 2001, different forms of wealth have shown different increases (see table 4). With respect to retirement wealth, Social Security wealth took up the largest share in 1983, accounting for 60 percent of the retirement wealth of age group 47-64. However, by 2001, pension wealth was the larger component, comprising 52 percent of retirement wealth, RW. DC wealth by itself comprised 33 percent of RW in comparison to 19 percent for DB wealth. In 1983, in contrast, DB made up 37 percent of RW and DC virtually nothing. In terms of growth rates, mean PW almost doubled over the 1983-2001 period, while mean SSW gained only 21 percent. ${ }^{16}$

The wealth distribution differs across retirement wealth categories. This means that separate groups of households will rely on different forms of retirement wealth to varying degrees.

Specifically, Social Security wealth was more equally distributed than other forms of retirement wealth. The average Social Security wealth for households between the ages of 47 and 64 was $\$ 184,500$ in 2001, or only 4.6 percent higher than the median Social Security wealth for this age group. In comparison, average private pension wealth for this age group was almost three times the median private pension wealth, hence, the wealth distribution reflects the less than universal coverage of private pension plans, as well as a more unequal distribution of private pension wealth.

Mean retirement wealth also grew robustly over the years 1983 to 2001, advancing by more than half, while median RW increased by a respectable 22 percent. Results are different for total (augmented) household wealth. Over the years 1983 to 2001, mean AW gained 32 percent, while median AW was up by a meager 3.4 percent. Thus, most of the gains in augmented wealth accrued to richer households.

For middle class households, those in the middle three income quintiles, the importance of Social Security becomes even more apparent (table 5). In 2001, SSW comprised 57 percent of their retirement wealth, as compared to 48 percent for all households in this age group. Since 1989, it

\footnotetext{
${ }^{16}$ Both mean and median SSW declined slightly from 1983 to 1989 . This change mainly reflects the increase in the normal retirement age for Social Security benefits, which came into effect in the early 1980s. The age at which full Social Security benefits begin advances from 65 and 2 months for those born in 1938 to 67 for those born in 1960 or later.
} 
declined as a share of RW by a mere 0.4 percentage points, much less than the 8.6 percentage point decline for all households in the age group.

Both pension wealth and Social Security wealth grew robustly for middle income families nearing retirement. As a result, mean retirement wealth gained 47 percent for age group 47 to 64 between 1989 and 2001, about the same as for all households in the age group, and augmented wealth was up by 38 percent, somewhat more than for all households in the age bracket.

\section{A. Retirement Wealth by Race}

As the distribution of retirement wealth has become more unequal, the question is whether certain demographic groups are more likely than others to have seen below or above average increases in retirement wealth and retirement income adequacy. We analyze retirement wealth and retirement income adequacy by two demographic characteristics: race and family status.

Despite improvements, minority households (defined here as African-Americans and Hispanics $)^{17}$ still had considerably less wealth accumulated than non-minority households as they approached retirement in 2001. For households between the ages of 47 and 64, the mean retirement wealth of non-Hispanic whites was almost two and a half times larger than for minorities in 2001 (table 6). The ratio of median retirement wealth was very similar.

Differences are even more extreme for net worth. In the age group 47 to 64, whites had 5.5 the net worth of non-whites in 2001 (table 7). Differences are less pronounced for total (augmented) wealth. The ratio of average total (augmented) wealth of non-Hispanics whites to the average wealth of minorities in 2001 was 3.6 for households between the ages of 47 and 64 (table 7) and the ratio of median AW was 2.9. These results once again highlight the equalizing effect of Social Security. In fact, in 2001, the ratio of mean SSW between the two groups was (only) 2.0.

African-American and Hispanic households made no progress in closing the large gap with respect to white households in terms of retirement wealth or total wealth. In fact, the gaps widened between 1983 and 2001. While mean RW gained 84 percent for whites, it actually lost 1 percent for minorities (table 6). Even more extreme differences are apparent for median retirement wealth. There was a huge gap in the growth rates of mean pension wealth between the two races, with the ratio of mean PW between minorities and whites slipping from 0.66 to 0.35 over this period. The

\footnotetext{
${ }^{17}$ Because of small sample sizes, I have combined these two groups. Moreover, I have excluded the group "Asians and other races" for the same reason.
} 
switchover from the traditional DB system to the newer DC pension system hurt minorities much more than white households.

As a result of the growing cleavage in retirement wealth, the gap in augmented wealth also widened over the period. This was the case despite the fact that the (large) net worth gap actually narrowed somewhat over the 1983-2001 period (from a ratio of 5.8 to 5.5). The ratio of mean augmented wealth grew from 2.7 to 3.6 over the period and the ratio of median AW from 2.1 to 2.9.

\section{B. Retirement Wealth by Marital Status}

Another important demographic distinction is based on marital status. We analyze levels and trends of retirement wealth and total wealth for married couples, single females, and single males. Our results show that married couples had substantially more retirement wealth and total wealth than single households, and that single male-headed households had more wealth than single female headed households in 2001. Further, the analysis also shows that single women fell further behind single men and married couples from 1983 to 2001.

Total accumulated wealth still differed widely by marital status in 2001. Single women typically had less than single men, who had less than married couples. Single women had only 31 percent of the mean retirement wealth that couples had in 2001 (table 8) and between 29 and 32 percent of their median retirement wealth. Single women had between 58 percent of the mean RW that single men had (and 61 percent of their median RW). Further, the ratio of mean RW for single men to that of married couples in 2001 was 54 percent and the ratio of median RW was 52 percent.

Single women were better off relative to married couples in terms of Social Security than in terms of pensions. In 2001, single women held 38 percent of the Social Security wealth of married couples and between only 25 percent of the pension wealth of couples. On the other hand, single males in age group 47 to 64 had 55 percent of the pension wealth of married couples in 2001, compared to 53 percent of their Social Security wealth.

Single women were at about the same level relative to married couples in terms of net worth and total augmented wealth as in terms of retirement wealth (table 9). In 2001, the ratio of mean AW between the two groups was 29 percent, compared to 28 percent for net worth and 31 percent for RW. The ratio of median AW was 28 percent. The ratio of mean AW between single males and couples in 2001 was 36 percent, while the ratio of median AW was 47 percent. 
Single women not only had less wealth than married couples or single men in 2001, but they also generally fell further behind over the period from 1983 to 2001. With respect to average retirement wealth, single men saw, by far, the largest gains from 1983 to 2001 at 128 percent, whereas single women saw much smaller gains than either single men or married couples. The same pattern held for median retirement wealth. Single women did make a substantial gain in terms of mean Social Security wealth but experienced an absolute decline in their pension wealth.

With respect to mean and median augmented wealth, single men and married couples had much larger gains than single women. The ratio of mean AW between single females and married couples fell from 33 to 29 percent between 1983 and 2001 and that of median AW plunged from 39 to 28 percent. Indeed, median AW actually declined in absolute terms for single females.

\section{RETIREMENT INCOME ADEQUACY}

I now turn to the primary topic of the paper, changes in retirement income adequacy. Retirement income is based on four components: (1) standard wealth holdings; (2) DC pension holdings; (3) DB pensions; and (4) Social Security. Standard net worth, excluding DC pensions (NWX), is first projected forward to year of retirement using a 3 percent real rate of return. This rate was chosen because it is approximately the average real rate of return on the average household portfolio from 1960 to 2000 (see Wolff, Zacharias, and Caner 2003, for details). An income flow equal to a seven percent real rate of return on projected wealth at retirement is then used to estimate income from wealth at retirement. ${ }^{18}$ It should be stressed that I am not attempting to fully model the savings behavior of households nearing retirement, as one can do in a microsimulation model. As a result, my estimates of retirement income (and replacement rates) should be viewed as lower bounds. However, they are useful for comparing retirement preparedness of an age group at two points in time, such as 1989 and 2001, to determine whether there is improvement or deterioration.

The second component, DC pensions, is treated in exactly the same way as NWX. For the third component, I use either the respondent's estimates of his (or her) annual pension benefit at retirement or my estimated value (see Section 3 above). The fourth component, annual Social Security benefits, is based on my estimated value of PIA (see Section 3 above).

\footnotetext{
${ }^{18}$ It should be noted that I am using net worth, including houses, in computing the annuity flow here and treating the net equity in homes as an asset value like stocks or bonds.
} 
I then measure retirement adequacy in three ways. The first is the annual projected retirement income. The second is the percentage of households whose projected retirement income is greater than twice the poverty threshold. ${ }^{19}$ The third is the income replacement rate. This is based on projected retirement income and projected income up to the year of retirement. For the latter, I use a 2.045 percent annual growth rate of real income, an estimate based on the growth of real income for age group 47 to 64 over the period 1983 to 2001 . Because the underlying data in the 1983 SCF do not permit an estimate of either Social Security or DB benefits at retirement, I show results only for 1989 and 2001.

\section{A. Mean Retirement Income}

The mean retirement income for all households in age group 47 to 64 in 2001 is estimated to be $\$ 74,800$ (see table 10). This compares to the actual mean income of this group in 2001 of $\$ 91,500$. In 2001, 59.4 percent of total retirement income is projected to come from this group's net worth, down from 64.8 percent in 1989; 23.3 percent from pensions, up from 16.5 percent in 1989; and the remaining 17.3 from Social Security, down slightly from 18.6 percent in 1989. The biggest change is the portion from DC pensions, which is estimated to grow by 11.0 percentage points, from 5.4 to 16.4 percent of total retirement income.

Projected retirement income is also estimated to have grown very strongly between 1989 and 2001. Among all households in age group 47 to 64, expected mean retirement income increased by 38 percent, for age group $47-55$ by 31 percent and for age group $56-64$ by 48 percent. The biggest growth is in DC pensions, more than tripling in real terms between 1989 and 2001, while annual benefits from DB plans are expected to decline by 13 percent in absolute terms.

Because of the widening racial gap in both retirement wealth and total augmented wealth, minorities are expected to fall behind non-Hispanic whites in retirement income-a 14 percent increase between 1989 and 2001 versus a 45 percent gain. By 2001, the mean retirement income of minorities is expected to be about one fourth that of white households. This compares to an actual income ratio among 47-64 year olds between the two groups of 42 percent in 2001. In fact, the ratio of minority to white retirement income is projected to fall from 0.329 in 1989 to 0.259 in 2001. Minorities will obtain a much higher share of their retirement income from Social Security -0.305

\footnotetext{
${ }^{19}$ I assume that the family's marital status remains unchanged over time.
} 
versus 0.156 in 2001 - and a higher share from pensions - 0.318 versus 0.266 - and a correspondingly much smaller share from standard wealth holdings -0.377 versus 0.578 .

Despite the fact that the retirement wealth and total augmented wealth of single females declined relative to married couples between 1989 and 2001, their actual retirement prospects showed a slight relative improvement. Their expected retirement income gained 53 percent between 1989 and 2001, compared to a 47 percent increase for married couples (and a 57 percent increase for single males). Still, in 2001, the mean expected retirement income of single females was only 29.4 percent that of married couples, though up from 28.3 percent in 1989. Single females in 2001 will obtain a higher percent of their retirement income from Social Security than married couples20.1 versus 15.7 percent—but a lower fraction from pensions-21.7 versus 27.1 percent.

\section{B. Twice the Poverty Threshold}

In 2001, 34.6 percent of households in age group 47 to 64 were projected to have retirement income less than twice the poverty line for their family size (table 11). The percentage was smaller for older age groups, falling from 37.3 percent for ages 47 to 55 to 30.5 percent for ages 56 to 64 . Only 27.5 percent of white households are projected to fall below twice the poverty standard, compared to almost two-thirds (64.4 percent) of minorities. Differences were also marked by marital status, with only 20.0 percent of married couples, compared to 64.6 percent of single females, falling below twice the poverty line.

A comparison of the two sets of columns reveals the importance of retirement assets for retirement income. In 2001, 70.6 percent of households in ages 47-64 are projected to have retirement income below twice the poverty line on the basis of their net worth alone (excluding DC pensions), compared to 34.6 percent on the basis of both net worth and retirement assets - a difference of 36.0 percentage points. Differences are greater for the older age group than the younger one (38.7 versus 34.2 percentage points), for whites than for minorities (38.3 versus 27.1 percentage points), and for married couples than single men or single women (43.7 versus 34.8 and 17.9 percentage points).

All groups saw a reduction in the share with expected retirement income less than twice the poverty line between 1989 and 2001. Overall, there was a 4.9 percentage point decline. Percentage points decline were much greater for age group 46-64 than 47-55. Minority households experienced a much greater decline than white households-11.6 versus 1.4 percentage points. 
Single males also saw a large decline- 13.6 percentage points - especially compared to married couples ( 4.0 percentage point decline) and single females (5.7 percentage point decline). All groups saw a bigger reduction in the share with expected retirement income less than twice the poverty line from increases in the sum of net worth plus retirement income than from increases in net worth alone. These results reflect the growing importance of DC pension wealth over time.

\section{Replacement Rates}

Changes in the share of households with expected retirement income greater than one half of projected income at retirement were much smaller than changes in the share that would fall short of twice the poverty standard. The reason is that the former is a relative standard whereas the latter is an absolute standard. Changes in the replacement rate reflect changes in both expected retirement income and preretirement income itself (which is projected to grow at about 2 percent per year).

In 2001, only 53.4 percent of all households in age group 47 to 64 are expected to have replacement rates more than 50 percent (table 12). The share with at least a 50 percent replacement rate increased by 4.5 percentage points between 1989 and 2001. The share also rises with age, from 42.2 percent for age group 47-55 to 70.5 percent for age group 56-64. Moreover, the older group experienced the greater increase in the proportion meeting this standard between 1989 and 2001 ( 9.5 percentage points versus 4.6 percentage points for the younger group).

Despite the higher preretirement income of whites, the share with replacement rates over half was 58.2 percent in 2001, compared to 32.2 percent for minorities. Moreover, the share of minority households that could replace less than 50 percent of their preretirement income remained almost unchanged between 1989 and 2001, while the share of white household increased by 4.2 percentage points.

Likewise, despite the lower preretirement income of single females, the share with a replacement rate over 50 percent was much lower for single females ( 42.5 percent) than for married couples (59.4 percent) or single men (47.9 percent). Moreover, single women saw a smaller improvement in retirement income adequacy, at least if a replacement standard is used, than married couples between 1989 and 2001 (1.8 versus 7.7 percentage points), while single men saw an absolute decline.

It is also of note that the share of households aged 47 to 64 that could replace at last half their income on the basis of net worth alone (excluding DC pensions) was only 8.6 percent in 2001, compared to 53.4 percent on the basis of the sum of net worth and retirement income (a difference 
of 44.8 percentage points). As with twice the poverty threshold standard, differences are greater for the older than younger age group (44.6 versus 29.0 percentage points), for whites than for minorities (37.3 versus 25.8 percentage points), and for married couples than single men or single women (39.7 versus 34.6 and 24.1 percentage points). It is also of note that the increases in replacement rates that occurred from 1989 to 2001 emanated largely from accumulations of retirement assets rather than increases in net worth.

Similar patterns exist when we look at different cut-off points for replacement rates (table 13). Declines in the proportion of households that fall below each of the four replacement rate standards are almost across the board (the notable exception being single males). Using a 75 percent replacement standard, the share of all households in age group 47-64 falling below this standard declined by 2.9 percentage points from 1989 to 2001 . The decline was even larger among age group 56-64 (6.3 percentage points) and married couples (4.7 percentage points).

\section{CONCLUSION}

Retirement income adequacy has gained in importance over the decades as the share of the population nearing retirement has grown. The starting point for retirement income adequacy is an assessment of how much wealth households have accumulated by the time they are about to retire.

The analysis here focuses on the wealth accumulation of households nearing retirement, between the ages of 47 and 64 . The data show that still many households have to rely solely on Social Security for their retirement income. Almost one quarter of all households nearing retirement had no private pension plans in 2001.

Also, retirement wealth is very unevenly distributed. Whites, married couples, and men had substantially larger wealth accumulations than their respective counterparts. However, expected retirement income grew robustly from 1989 to 2001 (by 38 percent in real terms) and the share with expected retirement income less than twice the poverty line fell by 5 percentage points. The percentage point decline was even greater for minority households (11.6) and single females (5.7). The change in the share with replacement rates over 50 percent was 4.5 percentage points, though in this case much lower for minorities ( 0.9 percentage points) and single females (1.8 percentage points). However, percentage point changes were much smaller at the 75 percent and 100 percent replacement rates. 


\section{REFERENCES}

Aon Consulting. 2001. Replacement Ratio Study. Chicago, IL: Aon Consulting.

Bloom, David E. and Richard B. Freeman. 1992. "The Fall in Private Pension Coverage in the United States.” American Economic Review Papers and Proceedings 82(2): 539-558.

Engen, E.M., W.G. Gale, and C.E. Uccello. 1999. "The Adequacy of Household Saving.” Brookings Papers on Economic Activity 2: 65-165.

Engen, E., W. Gale, and, C. Uccello. 2002. "Effects of Stock Market Fluctuations on the Adequacy of Retirement Wealth Accumulation." Paper prepared for the annual meetings of the American Economics Association, Washington, D.C., January 2003.

Even, William E. and David A. Macpherson. 1994. "Why Did Male Pension Coverage Decline in the 1980s?" Industrial and Labor Relations Review 47(April): 439-453.

Feldstein, Martin S. 1976. "Social Security and the Distribution of Wealth." Journal of the American Statistical Association 71(356): 800-807.

. 1974. "Social Security, Induced Retirement and Aggregate Capital Accumulation." Journal of Political Economy 82(5): 905-26.

Gustman, Alan L., Olivia S. Mitchell, Andrew A. Samwick, and Thomas L. Steinmeier. 1997. "Pension and Social Security Wealth in the Health and Retirement Study." Working Paper No. W5912. Cambridge, Mass.: National Bureau of Economic Research.

Gustman, Alan L. and Thomas L. Steinmeier. 1999. "What People Don't Know About Their Pensions and Social Security: An Analysis Using Linked Data from the Health and Retirement Study.” NBER Working Paper No. 7368, September.

1998. "Effects of Pensions on Saving: Analysis With Data From the Health and Retirement Study." Working Paper No. W6681. Cambridge, Mass.: National Bureau of Economic Research.

Haveman, R., K. Holden, B. Wolfe, and S. Sherlund. 2003. "Have Newly Retired Workers in the U.S. Saved Enough to Maintain Well-Being Through Retirement Years?" Paper presented at the annual meetings of the Association of Policy Analysis and Management (APPAM), Washington, D.C., November 2003.

Johnson, Richard W., Usha Sambamoorthi, and Stephen Crystal. 2000. "Pension Wealth at Midlife: Comparing Self-Reports with Provider Data." Review of Income and Wealth 46(1): 59-83.

Kennickell, Arthur B. and Annika E. Sunden. 1999. "Pensions, Social Security, and the Distribution of Wealth.” Mimeo, Federal Reserve Board, Washington, D.C. 
McGill, D.M., K.N. Brown, J. J. Haley, and S. Schieber. 1996. Fundamentals of Private Pensions, $7^{\text {th }}$ Edition. Philadelphia, PA: University of Pennsylvania Press.

Mitchell, Olivia S. and James Moore. 1998. "Can Americans Afford to Retire? New Evidence on Retirement Saving Adequacy.” Journal of Risk and Insurance 65(3): 371-400.

Mitchell, Olivia S., James Moore, and John Phillips. 2000. "Explaining Retirement Saving Shortfalls" In Forecasting Retirement Needs and Retirement Wealth, O.S. Mitchell, B. Hammond, and A. Rappaport (eds.) Philadelphia, PA: University of Philadelphia Press.

Moore, James F. and Olivia S. Mitchell. 2000. "Projected Retirement Wealth and Saving Adequacy.” In O. Mitchell, B. Hammond, and A. Rappaport (eds.) Forecasting Retirement Needs and Retirement Wealth. Philadelphia, PA: University of Pennsylvania Press.

Popke, Leslie E. 1999. “Are 401(k) Plans Replacing Other Employer-Provided Pensions?” Journal of Human Resources 34(2): 346-368.

Poterba, James M., Steven F. Venti, and David A. Wise. 1998. "401(k) Plans and Future Patterns of Retirement Saving." American Economic Review Papers and Proceedings 88(2): 179-184.

Smith, James P. 2003. "Trends and Projections in Income Replacement During Retirement." Journal of Labor Economics 21(4): 755-781.

U.S. Bureau of the Census. 2002. Statistical Abstract of the United States: 2002. Washington, D.C.: U.S. Government Printing Office.

U.S. Department of Labor, Pension and Welfare Benefits Administration. 2000. "Coverage Status of Workers Under Employer Provided Pension Plans: Findings From the Contingent Work Supplement to the February 1999 Current Population Survey." Washington, D.C.: Department of Labor.

Wolff, Edward N. 2002a. "Is the Equalizing Effect of Retirement Wealth Wearing Off?" unpublished working paper, Department of Economics, New York, NY: New York University.

. 2002b. Retirement Insecurity: The Income Shortfalls Awaiting the Soon-to-Retire. Washington, D.C.: Economic Policy Institute.

. 2001. "Recent Trends in Wealth Ownership, From 1983 to 1998." In Thomas M. Shapiro and Edward N. Wolff, (eds.) Assets for the Poor: The Benefits of Spreading Asset Ownership. New York: Russell Sage Press.

1987. "The Effects of Pensions and Social Security on the Distribution of Wealth in the U.S." In E. Wolff (ed.) International Comparisons of Household Wealth Distribution. Oxford, England: Oxford University Press. 
forthcoming. "The Transformation of the American Pension System.” In T. Ghilarducci and J. Turner (eds.) Work Options for Older Americans. Notre Dame, IN: University of Notre Dame Press.

Wolff, Edward N., Ajit Zacharias and Asena Caner. 2003. The Levy Institute Measure of Economic Well-Being. Annandale-on-Hudson, NY: The Levy Economics Institute of Bard College. 


\begin{tabular}{|c|c|c|c|c|c|c|}
\hline \multicolumn{7}{|c|}{$\begin{array}{l}\text { Table 1: Mean and Median Household Wealth and Income, 1983, 1989, and } 2001 \\
\text { (in thousands, } 2001 \text { dollars) }\end{array}$} \\
\hline & 1983 & 1989 & 2001 & 1983-89 & 1989-2001 & 1983-2001 \\
\hline \multicolumn{7}{|l|}{ Net worth } \\
\hline 1. Median & 59.3 & 63.5 & 73.5 & 7.0 & 15.8 & 23.9 \\
\hline 2. Mean & 231.0 & 264.6 & 380.1 & 14.6 & 43.7 & 64.6 \\
\hline \multicolumn{7}{|l|}{ Income } \\
\hline 1. Median & 34.7 & 35.7 & 39.0 & 3.0 & 9.2 & 12.5 \\
\hline 2. Mean & 49.5 & 53.3 & 67.2 & 7.8 & 26.2 & 36.0 \\
\hline
\end{tabular}

Table 2: Household Net Worth and Income, Ages 47-64, 1983, 1989, and 2001 (in thousands, 2001 dollars)

\begin{tabular}{|c|c|c|c|c|c|c|}
\hline & \multirow[b]{2}{*}{1983} & \multirow[b]{2}{*}{1989} & \multirow[b]{2}{*}{2001} & \multicolumn{3}{|c|}{ Percentage change } \\
\hline & & & & 1983-89 & $\begin{array}{l}1989- \\
2001\end{array}$ & $\begin{array}{l}1983- \\
2001\end{array}$ \\
\hline 1. Mean net worth (NW) & 373.3 & 407.4 & 598.3 & 9.2 & 46.9 & 60.3 \\
\hline 2. Median net worth (NW) & 108.3 & 133.2 & 137.6 & 23.0 & 3.3 & 27.0 \\
\hline 3. Mean income & 63.3 & 68.1 & 91.5 & 7.6 & 34.3 & 44.5 \\
\hline 4. Median income & 41.9 & 42.8 & 49.0 & 2.3 & 14.4 & 17.0 \\
\hline
\end{tabular}

Source: Authors' computations from the 1983, 1989, and 2001 Survey of Consumer Finances.

Note: Households are classified by the age of the head of household. 


\begin{tabular}{|c|c|c|c|c|c|c|}
\hline \multicolumn{7}{|c|}{$\begin{array}{l}\text { Table 3: Percentage of Households with Retirement Wealth, Ages 47-64, 1983, 1989, } \\
\text { and } 2001 \text { (in percentage points) }\end{array}$} \\
\hline & 1983 & 1989 & 2001 & 1983-89 & 1989-2001 & $\begin{array}{l}1983- \\
2001\end{array}$ \\
\hline 1. DC pensions & 11.9 & 28.3 & 62.4 & 16.4 & 34.1 & 50.5 \\
\hline 2. DB pension wealth & 68.9 & 56.8 & 45.3 & -12.1 & -11.5 & -23.6 \\
\hline 3. Pension wealth (PW) & 70.1 & 67.6 & 76.3 & -2.5 & 8.7 & 6.2 \\
\hline 4. Social Security wealth (SSW) & 92.1 & 96.2 & 97.9 & 4.1 & 1.7 & 5.8 \\
\hline 5. Retirement wealth (RW) & 97.0 & 97.1 & 98.1 & 0.1 & 1.1 & 1.1 \\
\hline \multicolumn{7}{|c|}{$\begin{array}{l}\text { Source: Authors' computations from the 1983, 1989, and } 2001 \text { Survey of Consumer Finances. } \\
\text { Note: Households are classified by the age of the head of household. Key: } \\
\text { Pension Wealth PW = DB + DC } \\
\text { Retirement Wealth RW = PW+SSW. }\end{array}$} \\
\hline
\end{tabular}

\begin{tabular}{|c|c|c|c|c|c|c|}
\hline \multicolumn{7}{|c|}{ 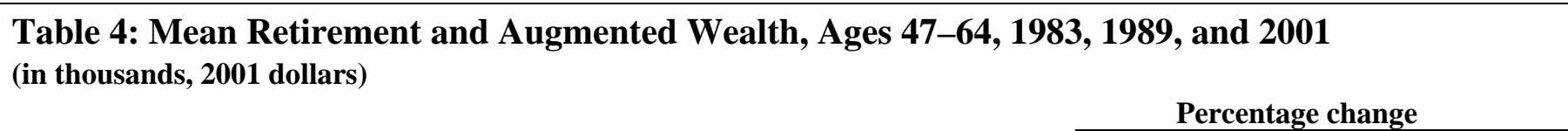 } \\
\hline & 1983 & 1989 & 2001 & \multicolumn{2}{|c|}{ 198--89 1989-2001 } & 1983-2001 \\
\hline 1. DC pensions & 8.0 & 28.9 & 127.3 & 260.9 & 340.2 & 1488.8 \\
\hline 2. DB pension wealth & 94.6 & 85.6 & 74.3 & -9.5 & -13.3 & -21.5 \\
\hline 3. Pension wealth (PW) & 102.6 & 114.6 & 201.6 & 11.7 & 76.0 & 96.5 \\
\hline 4. Social Security wealth (SSW) & 152.7 & 147.8 & 184.5 & -3.2 & 24.8 & 20.8 \\
\hline 5. Retirement wealth (RW) & 255.3 & 262.3 & 386.1 & 2.8 & 47.2 & 51.2 \\
\hline 6. Augmented wealth (AW) & 589.9 & 632.9 & 782.8 & 7.3 & 23.7 & 32.7 \\
\hline \multicolumn{7}{|l|}{ Memo } \\
\hline 6. Median pension wealth (PW) & 42.4 & 41.4 & 69.0 & -2.3 & 66.5 & 62.8 \\
\hline 7. Median Social Security wealth (SSW) & 144.7 & 142.8 & 176.3 & -1.3 & 23.5 & 21.9 \\
\hline 8. Median retirement wealth (RW) & 212.7 & 207.1 & 259.6 & -2.7 & 25.4 & 22.0 \\
\hline 9. Median augmented wealth (AW) & 376.4 & 367.8 & 389.2 & -2.3 & 5.8 & 3.4 \\
\hline
\end{tabular}




\begin{tabular}{|lrrr|}
\hline $\begin{array}{l}\text { Table 5: Mean Income and Wealth, Middle Three Income Quintiles, } \\
\text { Ages 47-64, } 1989 \text { and } 2001 \\
\text { (in thousands, 2001 dollars) }\end{array}$ & & & \\
& & & Percent change \\
& 1989 & 2001 & $1989-2001$ \\
\hline 1. Mean income & 44.7 & 52.7 & 18.0 \\
2. Mean net worth (NW) & 199.1 & 255.5 & 28.3 \\
3. Mean pension wealth (PW) & 94.5 & 137.5 & 45.6 \\
4. Mean Social Security wealth (SSW) & 122.6 & 181.6 & 48.2 \\
5. Mean retirement wealth (RW) & 217.0 & 319.1 & 47.1 \\
6. Mean augmented wealth (AW) & 416.1 & 574.6 & 38.1 \\
\hline Source: Authors' computations from the 1983 and 2001 SCF. & & \\
Note: Households are classified by the age of the head of household. Key: & \\
& & & \\
& & & \\
& & & \\
Pension Wealth PW $=$ DB + DC \\
Retirement Wealth RW $=$ PW+SSW. \\
Augmented Wealth AW = NWX+RW.
\end{tabular}

\begin{tabular}{|c|c|c|c|c|c|c|}
\hline \multicolumn{7}{|c|}{$\begin{array}{l}\text { Table 6. Retirement Wealth by Race/Ethnicity, Ages 47-64, 1983, 1989, and } 2001 \\
\text { (In thousands, } 2001 \text { dollars) }\end{array}$} \\
\hline Category & 1983 & 1989 & 2001 & 1983-1989 & 1989-2001 & $\begin{array}{l}1983- \\
2001\end{array}$ \\
\hline \multicolumn{7}{|l|}{ A. Non-Hispanic White } \\
\hline Mean Pension Wealth (PW) & 110.1 & 134.1 & 229.5 & 21.8 & 71.2 & 108.5 \\
\hline Mean Social Security Wealth (SSW) & 161.1 & 140.4 & 204.3 & -12.8 & 45.5 & 26.8 \\
\hline Mean Retirement Wealth (RW) & 271.2 & 274.5 & 433.8 & 1.2 & 58.0 & 60.0 \\
\hline Median Retirement Wealth (RW) & 224.9 & 196.3 & 301.8 & -12.7 & 53.8 & 34.2 \\
\hline \multicolumn{7}{|l|}{ B. African-American or Hispanic } \\
\hline Mean Pension Wealth (PW) & 72.5 & 56.1 & $\mathbf{8 0 . 0}$ & -22.6 & 42.6 & 10.3 \\
\hline Mean Social Security Wealth (SSW) & 112.5 & 110.4 & 103.2 & -1.9 & -6.5 & -8.3 \\
\hline Mean Retirement Wealth (RW) & 185.0 & 166.5 & 183.2 & -10.0 & 10.0 & -1.0 \\
\hline Median Retirement Wealth (RW) & 146.4 & 124.6 & 124.3 & -14.9 & -0.3 & -15.1 \\
\hline $\begin{array}{l}\text { Source: author's computations from th } \\
\text { Households are classified by the age of } \\
\text { excluded from the table because of sm } \\
\text { Retirement Wealth RW = PW+SSW }\end{array}$ & $\begin{array}{l}\text { and } 2 \\
\text { louseho } \\
\text { es. Key }\end{array}$ & $\begin{array}{l}01 \text { SC } \\
\text { ld. As }\end{array}$ & is and & races are & & \\
\hline
\end{tabular}




\begin{tabular}{|c|c|c|c|c|c|c|}
\hline \multirow[b]{2}{*}{ Category } & \multicolumn{3}{|c|}{ Mean Value } & \multicolumn{3}{|c|}{ Percentage Change } \\
\hline & 1983 & 1989 & 2001 & 1983-1989 & 1989-2001 & $\begin{array}{l}1983- \\
2001 \\
\end{array}$ \\
\hline \multicolumn{7}{|l|}{ A. Non-Hispanic White } \\
\hline Mean Income & 69.3 & 78.1 & 103.7 & 12.7 & 32.7 & 49.5 \\
\hline Mean Net Worth (NW) & 433.3 & 485.8 & 710.7 & 12.1 & 46.3 & 64.0 \\
\hline Mean Augmented Wealth (AW) & 695.4 & 724.6 & 996.5 & 4.2 & 37.5 & 43.3 \\
\hline Median Augmented Wealth (AW) & 412.1 & 390.3 & 469.9 & -5.3 & 20.4 & 14.0 \\
\hline \multicolumn{7}{|l|}{ B. African-American or Hispanic } \\
\hline Mean Income & 34.4 & 30.6 & 44.1 & -11.0 & 44.2 & 28.3 \\
\hline Mean Net Worth (NW) & 74.4 & 100.6 & 130.1 & 35.1 & 29.3 & 74.7 \\
\hline Mean Augmented Wealth (AW) & 256.1 & 260.4 & 278.2 & 1.7 & 6.8 & 8.6 \\
\hline Median Augmented Wealth (AW) & 194.5 & 182.1 & 161.9 & -6.4 & -11.1 & -16.8 \\
\hline $\begin{array}{l}\text { Source: author's computations from } \\
\text { Households are classified by the age } \\
\text { excluded from the table because of } s \\
\text { Augmented Wealth AW }=\mathrm{NWX}+1\end{array}$ & $\begin{array}{l}\text { 89, and } \\
\text { f hous } \\
\text { izes. K }\end{array}$ & $\begin{array}{l}2001 \mathrm{~S} \\
\text { hold. A } \\
\text { ey }\end{array}$ & $\begin{array}{l}\text { F.. } \\
\text { lans at }\end{array}$ & her races ar & & \\
\hline
\end{tabular}




\begin{tabular}{|c|c|c|c|c|c|c|}
\hline \multirow[b]{2}{*}{ Category } & \multicolumn{3}{|c|}{ Mean Value } & \multicolumn{3}{|c|}{ Percentage Change } \\
\hline & 1983 & 1989 & 2001 & 1983-1989 & 1989-2001 & $\begin{array}{l}1983- \\
2001 \\
\end{array}$ \\
\hline \multicolumn{7}{|l|}{ A. Married Couple } \\
\hline Mean Pension Wealth (PW) & 119.2 & 147.9 & 271.0 & 24.1 & 83.2 & 127.3 \\
\hline Mean Social Security Wealth (SSW) & 198.3 & 189.1 & 239.2 & -4.6 & 26.5 & 20.6 \\
\hline Mean Retirement Wealth (RW) & 317.5 & 337.1 & 510.1 & 6.2 & 51.3 & 60.7 \\
\hline Median Retirement Wealth (RW) & 276.0 & 266.3 & 355.5 & -3.5 & 53.5 & 28.8 \\
\hline \multicolumn{7}{|l|}{ B. Single Male } \\
\hline Mean Pension Wealth (PW) & 47.8 & 59.4 & 148.0 & 24.4 & 149.0 & 209.8 \\
\hline Mean Social Security Wealth (SSW) & 72.8 & 76.5 & 127.1 & 5.0 & 66.1 & 74.5 \\
\hline Mean Retirement Wealth (RW) & 120.6 & 135.9 & 275.1 & 12.7 & 102.3 & 128.1 \\
\hline Median Retirement Wealth (RW) & 96.3 & 97.0 & 185.9 & 0.7 & 91.7 & 93.0 \\
\hline \multicolumn{7}{|l|}{ C. Single Female } \\
\hline Mean Pension Wealth (PW) & 73.3 & 56.3 & 68.8 & -23.2 & 22.2 & -6.2 \\
\hline Mean Social Security Wealth (SSW) & 61.3 & 70.6 & 90.0 & 15.3 & 27.4 & 46.8 \\
\hline Mean Retirement Wealth (RW) & 134.6 & 127.0 & 158.8 & -5.7 & 25.1 & 17.9 \\
\hline Median Retirement Wealth (RW) & 111.1 & 103.9 & 113.3 & -6.4 & 9.0 & 2.0 \\
\hline
\end{tabular}




\begin{tabular}{|c|c|c|c|c|c|c|}
\hline \multirow[b]{2}{*}{ Category } & \multicolumn{3}{|c|}{ Mean Value } & \multicolumn{3}{|c|}{ Percentage Change } \\
\hline & 1983 & 1989 & 2001 & 1983-1989 & 1989-2001 & $\begin{array}{l}1983- \\
2001 \\
\end{array}$ \\
\hline \multicolumn{7}{|l|}{ A. Married Couple } \\
\hline Mean Income & 79.2 & 88.5 & 117.5 & 11.8 & 32.8 & 48.5 \\
\hline Mean Net Worth (NW) & 493.3 & 546.0 & 824.2 & 10.7 & 51.0 & 67.1 \\
\hline Mean Augmented Wealth (AW) & 810.8 & 883.0 & 1334.4 & 8.9 & 51.1 & 64.6 \\
\hline Median Augmented Wealth (AW) & 473.9 & 473.3 & 556.9 & -0.1 & 17.7 & 17.5 \\
\hline \multicolumn{7}{|l|}{ B. Single Male } \\
\hline Mean Income & 35.5 & 46.9 & 77.6 & 32.0 & 65.4 & 118.5 \\
\hline Mean Net Worth (NW) & 183.2 & 227.4 & 333.2 & 24.1 & 46.5 & 81.9 \\
\hline Mean Augmented Wealth (AW) & 294.5 & 342.4 & 478.3 & 16.3 & 39.7 & 62.4 \\
\hline Median Augmented Wealth (AW) & 165.4 & 195.4 & 261.5 & 18.2 & 33.8 & 58.1 \\
\hline \multicolumn{7}{|l|}{ C. Single Female } \\
\hline Mean Income & 31.4 & 26.7 & 37.1 & -15.0 & 38.9 & 18.1 \\
\hline Mean Net Worth (NW) & 129.3 & 143.2 & 227.7 & 10.8 & 59.0 & 76.1 \\
\hline Mean Augmented Wealth (AW) & 263.9 & 270.2 & 386.4 & 2.4 & 43.0 & 46.4 \\
\hline Median Augmented Wealth (AW) & 182.8 & 163.2 & 158.2 & -10.7 & -3.1 & -13.5 \\
\hline
\end{tabular}




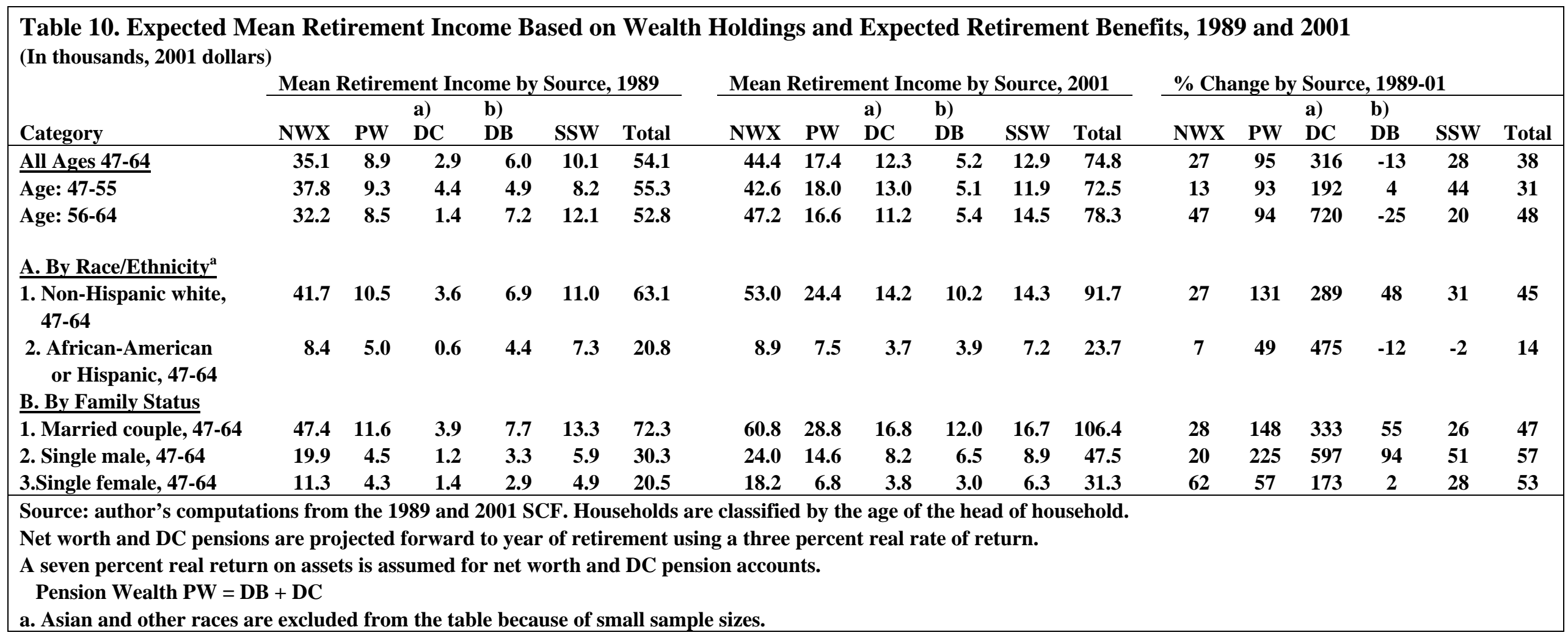




\begin{tabular}{|c|c|c|c|c|c|c|}
\hline & \multicolumn{3}{|c|}{$\begin{array}{l}\text { From Marketable Wealth } \\
\text { (NWX) Holdings Only }\end{array}$} & \multicolumn{3}{|c|}{$\begin{array}{l}\text { From Marketable Wealth } \\
\text { and Expected Retirement } \\
\text { Benefits }\end{array}$} \\
\hline & & & Change & & & Change \\
\hline & 1989 & 2001 & 1989-2001 & 1989 & 2001 & 1989-2001 \\
\hline All Ages 47-64 & 69.6 & 70.6 & 1.0 & 39.5 & 34.6 & -4.9 \\
\hline Age: 47-55 & 67.4 & 71.5 & 4.1 & 37.7 & 37.3 & -0.4 \\
\hline Age: $56-64$ & 71.9 & 69.2 & -2.7 & 41.4 & 30.5 & -10.9 \\
\hline \multicolumn{7}{|l|}{ A. By Race/Ethnicity ${ }^{\text {a }}$} \\
\hline 1. Non-Hispanic white, 47-64 & 64.2 & 65.8 & 1.6 & 28.9 & 27.5 & -1.4 \\
\hline 2. African-American or Hispanic, 47-64 & 91.8 & 91.5 & -0.2 & 76.0 & 64.4 & -11.6 \\
\hline \multicolumn{7}{|l|}{ B. By Family Status } \\
\hline 1. Married couple, $47-64$ & 64.5 & 63.8 & -0.8 & 24.1 & 20.0 & -4.0 \\
\hline 2. Single male, 47-64 & 71.3 & 77.4 & 6.1 & 56.2 & 42.6 & -13.6 \\
\hline 3. Single female, $47-64$ & 81.3 & 82.5 & 1.2 & 70.3 & 64.6 & -5.7 \\
\hline $\begin{array}{l}\text { Source: author's computations from the } \\
\text { Net worth and DC pensions are projected } \\
\text { A seven percent real return on assets is a } \\
\text { a. Asian and other races are excluded fro }\end{array}$ & $\begin{array}{l}\text { Househ } \\
\text { retirem } \\
h \text { and D } \\
\text { of smal }\end{array}$ & $\begin{array}{l}\text { ds are } \\
\text { t usin } \\
\text { pensi } \\
\text { ample }\end{array}$ & $\begin{array}{l}\text { assified by } t \\
\text { three perce } \\
\text { accounts. } \\
\text { zes. }\end{array}$ & $\begin{array}{l}f \text { the } h \\
\text { ate of }\end{array}$ & d. & \\
\hline
\end{tabular}




\begin{tabular}{|c|c|c|c|c|c|c|}
\hline & \multicolumn{3}{|c|}{$\begin{array}{l}\text { From Marketable Wealth } \\
\text { (NWX) Holdings Only }\end{array}$} & \multicolumn{3}{|c|}{$\begin{array}{l}\text { From Marketable Wealth } \\
\text { and Expected Retirement } \\
\text { Benefits }\end{array}$} \\
\hline & & & Change & & & Change \\
\hline & 1989 & 2001 & 1989-2001 & 1989 & 2001 & 1989-2001 \\
\hline All Ages 47-64 & 10.3 & 8.6 & -1.8 & 48.9 & 53.4 & 4.5 \\
\hline Age: 47-55 & 11.4 & 13.2 & 1.8 & 37.5 & 42.2 & 4.6 \\
\hline Age: $56-64$ & 21.3 & 25.9 & 4.6 & 61.0 & 70.5 & 9.5 \\
\hline \multicolumn{7}{|l|}{ A. By Race/Ethnicity } \\
\hline 1. Non-Hispanic white, 47-64 & 24.4 & 20.9 & -3.4 & 53.9 & 58.2 & 4.3 \\
\hline 2. African-American or Hispanic, 47-64 & 8.8 & 6.5 & -2.3 & 31.3 & 32.3 & 0.9 \\
\hline \multicolumn{7}{|l|}{ B. By Family Status } \\
\hline$\overline{\text { 1. Married couple, } 47-64}$ & 22.0 & 19.7 & -2.3 & 51.7 & 59.4 & 7.7 \\
\hline 2. Single male, $47-64$ & 26.7 & 13.3 & -13.4 & 51.4 & 47.9 & -3.5 \\
\hline 3.Single female, $47-64$ & 18.1 & 18.3 & 0.2 & 40.7 & 42.5 & 1.8 \\
\hline $\begin{array}{l}\text { Source: author's computations from the } 1 \\
\text { Net worth and DC pensions are projected } \\
\text { A seven percent real return on assets is as } \\
\text { a. Asian and other races are excluded fror }\end{array}$ & $\begin{array}{l}\text { ouseholc } \\
\text { irement } \\
\text { nd DC }\end{array}$ & $\begin{array}{l}\text { are cle } \\
\text { sing a } \\
\text { asion }\end{array}$ & $\begin{array}{l}\text { fied by the } \\
\text { ree percent } \\
\text { ounts. }\end{array}$ & $\begin{array}{l}\text { he head } \\
\text { te of ret }\end{array}$ & & \\
\hline
\end{tabular}




\begin{tabular}{|c|c|c|c|c|c|c|c|c|}
\hline \multicolumn{9}{|c|}{$\begin{array}{l}\text { Table 13. Distribution of Households in Age Group 47-64 by Expected Replacement Rates, } \\
\text { Based on Wealth Holdings and Expected Pension and Social Security Benefits, } 1989 \text { and } 2001 \\
\text { (in percentage points) }\end{array}$} \\
\hline & \multicolumn{4}{|c|}{ Income Replacement Rates, 1989} & \multicolumn{4}{|c|}{ Income Replacement Rates, 2001} \\
\hline & $<25 \%$ & $<50 \%$ & $<75 \%$ & $<100 \%$ & $<25 \%$ & $<50 \%$ & $<75 \%$ & $<\mathbf{1 0 0 \%}$ \\
\hline All Ages 47-64 & 17.4 & 51.1 & 70.7 & 82.2 & 15.6 & 46.6 & 67.8 & 79.2 \\
\hline Age: 47-55 & 23.3 & 62.5 & 79.7 & 88.2 & 22.2 & 57.8 & 76.3 & 85.7 \\
\hline Age: $56-64$ & 11.0 & 39.0 & 61.0 & 75.7 & 5.6 & 29.5 & 54.7 & 69.4 \\
\hline 1. Non-Hispanic white & 12.8 & 46.1 & 66.1 & 79.8 & 11.9 & 41.8 & 64.3 & 77.1 \\
\hline 2. African-American or Hispanic & 34.1 & 68.7 & 86.5 & 91.2 & 31.5 & 67.7 & 83.2 & 89.5 \\
\hline 3. Married couple & 10.9 & 48.3 & 70.0 & 84.1 & 10.6 & 40.6 & 65.3 & 77.6 \\
\hline 4. Single male & 16.9 & 48.6 & 64.9 & 74.1 & 20.2 & 52.1 & 70.4 & 82.4 \\
\hline 5. Single female & 33.7 & 59.3 & 74.8 & 81.0 & 24.6 & 57.5 & 72.0 & 81.2 \\
\hline \multicolumn{9}{|c|}{$\begin{array}{l}\text { Source: author's computations from the } 1989 \text { and } 2001 \text { SCF. Households are classified by the age of the head. } \\
\text { Net worth and DC pensions are projected forward to year of retirement using a three percent real rate of return. } \\
\text { A seven percent real return on assets is assumed for net worth and DC pension accounts. } \\
\text { a. Asian and other races are excluded from the table because of small sample sizes. }\end{array}$} \\
\hline
\end{tabular}

